\title{
Water Damage and Homeowner's Insurance: (1) Insurance Claim ${ }^{1}$
}

Hyun-Jeong Lee ${ }^{2}$

When you find water damage in your home, you may decide to report it to your insurance company so that your insurance policy pays the repairs. However, there are important things to keep in mind for your insurance claim process in order to avoid further damage to your property as well as unexpected financial loss caused by an insurance rate increase or even policy cancellation.

\section{Know Your Insurance Policy}

Homeowner insurance policy coverage varies with individual policies. Thus, it is very important to thoroughly read your insurance policy for details regarding your water damage coverage. Some insurance policies, for example, include details regarding your responsibilities for basic emergency remedies such as shutting off the water to prevent further damage.

\section{To Claim or Not to Claim}

Before contacting your insurance company, you need to decide if you want to make the claim. In Florida, reporting any damages on your home-regardless of whether it results in any payment by your insurance company-or even making a simple inquiry about your coverage results in documentation on your consumer report called C.L.U.E. ${ }^{\circledR}$ (Comprehensive Loss Underwriting Exchange) Personal Property report. This history may be used negatively by insurance companies to increase your homeowner's insurance rate, deny your insurance application, or cancel your current insurance policy (Private Rights Clearinghouse, 2005). For more information on the C.L.U.E.® database and your consumer rights, refer to EDIS publication FCS3304/FY1083 Water Damage and Homeowner's Insurance: (2) C.L.U.E. ${ }^{\circledR}$ Report (http://edis.ifas.ufl.edu/FY1083), or a factsheet by the Privacy Rights Clearinghouse, CLUE and You: How Insurers Size You Up (http://www.privacyrights.org/fs/fs26-CLUE.htm).

\section{Contact Your Insurance Company}

If you decide to file a claim of water damage, contact your insurance company and describe the damage in written or verbal format. In general, your insurance company should make written or verbal contact within 72 hours of notice of your claim. According to the Florida Department of Financial Services (FL DFS, 2007) the insurance company representative should provide the following:

1. This document is FCS 3303, one of a series of the Family Youth and Community Sciences Department, Florida Cooperative Extension Service, Institute of Food and Agricultural Sciences, University of Florida. Original publication date January 2009. Visit the EDIS Web site at http://edis.ifas.ufl.edu. 2. Hyun-Jeong Lee, assistant professor, Department of Family, Youth and Community, University of Florida, Gainesville, FL 32611.

The Institute of Food and Agricultural Sciences (IFAS) is an Equal Opportunity Institution authorized to provide research, educational information and other services only to individuals and institutions that function with non-discrimination with respect to race, creed, color, religion, age, disability, sex, sexual orientation, marital status, national origin, political opinions or affiliations. U.S. Department of Agriculture, Cooperative Extension Service, University of Florida, IFAS, Florida A. \& M. University Cooperative Extension Program, and Boards of County Commissioners Cooperating. Millie Ferrer, Interim Dean 
- name and contact information of a company representative who will oversee your claim

- information on emergency repairs and mold prevention

- determination as to whether or not your claim is covered under the terms of your policy

- advisement on your responsibilities under the terms of your insurance policy

Some adjusters may also provide a list of repair specialists in your area. However, it is your right to choose any vendor. FL DFS encourages consumers to check out a contractor through the Department of Business and Professional Regulation at (850) 487-1395 before signing a contract.

FL DFS (2007) recommends you not make any major repairs before contacting your insurance company and determining your loss coverage. But since the water damage needs to be fixed as soon as possible to prevent further damage to your property, it is critical to report the issue to your insurance company in a timely manner if you are unable to make the necessary repairs yourself.

\section{Prevent Mold Growth}

It is well known that Florida's year-round warm and humid climate promotes mold growth. Not all water damage results in mold. However, if the water-damaged area remains without any reasonable treatments to prevent mold growth, your damage may turn into a bigger problem. FL DFS (2007) emphasizes that a water damage claim involving active mold growth may result in significantly higher costs than claims without any mold damage. Recently, some insurance companies have excluded or limited insurance coverage of damages caused by mold and fungus (FL DFS, 2008).

To prevent mold growth and further water damage to your property, you may need to take reasonable actions as indicated in your insurance policy, including finding and fixing the source of the water problem and removing excess water. You may move wet items to dry them, but make sure to take photographs of the original damages and do not discard materials until your insurance company advises you to do so. For information on general mold cleanup tips, refer to EDIS publication FCS3301/FY1080 How to Clean Up Mold (http://edis.ifas.ufl.edu/FY1080).

\section{Keep Good Records}

Throughout the claim process, you must keep good records of your property damage, related repairs, and conversations with your insurance company. Make sure to keep records of all repairs and expenses with receipts, take photographs of the damages, and document all conversations in written format with dates. Doing so will help to minimize the risk of any misunderstanding between you and your insurance company and will also help to protect your consumer rights.

\section{Additional Living Expense (ALE) Coverage}

If water damage is so severe that you cannot stay in your home, you may need to find a temporary living arrangement. In this case, check your homeowner insurance policy for additional living expense (ALE) coverage. In general, ALE benefits cover extra costs for housing as well as reasonable expenses for moving and setup of temporary housing (relocation, storage, utility installation and/or furniture rentals), food, and expenses accrued for transportation to work or school (FL DFS, 2007).

\section{Water Damage Caused by Flood}

Most homeowner's insurance does not cover damage due to rising floodwater. For flood damage coverage, you need to purchase a separate flood insurance policy sanctioned by the National Flood Insurance Program, or NFIP (FL DFS, 2008). If you live in or are moving into a high-risk flood zone defined by the the Federal Emergency Management Agency (FEMA), you are required to purchase or maintain flood insurance to qualify for a mortgage loan from federally regulated or insured lenders (NFIP, n.d.). At the NFIP Web site (http://www.floodsmart.gov), you can find out about the risk profile of a property and obtain a list of local flood insurance agents in the area by using the property address. For more information on flood insurance policies and claims, refer to EDIS 
publication FCS3302/FY1081 Flood Insurance

(http://edis.ifas.ufl.edu/FY1081) or visit the NFIP

Web site.

\section{References}

Florida Department of Financial Services (2007). In the intrusion of unexpected water intrusion: Know your rights and responsibilities. Retrieved October 27, 2008, from http://www.myfloridacfo.com.

Florida Department of Financial Services (2008).

Insuring your home: A guide for consumers. Retrieved October 27, 2008, from

http://www.myfloridacfo.com.

National Flood Insurance Program (n.d.). Flood insurance policies: How to buy flood insurance. Retrieved November 5, 2008, from http://www.floodsmart.gov/floodsmart/pages/ flood_policies/howto_purchase_flood_insurance.jsp.

Privacy Rights Clearinghouse (2005). CLUE and you: How insurers size you up (Fact Sheet 26: CLUE Insurance Databases). Retrieved October 27, 2008, from http://www.privacyrights.org/fs/fs26-CLUE.htm\#2. 